\title{
Plant richness and composition in hardwood forest understories vary along an acidic deposition and soil-chemical gradient in the northeastern United States
}

\author{
Michael R. Zarfos (ID) Martin Dovciak • \\ Gregory B. Lawrence • Todd C. McDonnell • \\ Timothy J. Sullivan
}

Received: 2 July 2018 / Accepted: 18 February 2019 /Published online: 26 March 2019

(C) The Author(s) 2019

\begin{abstract}
Aims A century of atmospheric deposition of sulfur and nitrogen has acidified soils and undermined the health and recruitment of foundational tree species in the northeastern US. However, effects of acidic deposition on the forest understory plant communities of this region are poorly
\end{abstract}

Responsible Editor: Eric Paterson.

M. R. Zarfos $(\bowtie)$

Department of Environmental and Forest Biology, College of Environmental Science and Forestry, State University of New York, 1 Forestry Drive, 246 Illick Hall, Syracuse, NY 13210, USA e-mail: whalen.mike.r@gmail.com

\section{Dovciak}

Department of Environmental and Forest Biology, College of Environmental Science and Forestry, State University of New York, Syracuse, NY, USA

e-mail:mdovciak@esf.edu

G. B. Lawrence

U.S. Geological Survey, New York Water Science Center, Troy, NY, USA

e-mail: glawrenc@usgs.gov

T. C. McDonnell · T. J. Sullivan

E\&S Environmental Chemistry, Inc., Corvallis, OR, USA

T. C. McDonnell

e-mail: todd.mcdonnell@esenvironmental.com

T. J. Sullivan

e-mail: tim.sullivan@esenvironmental.com documented. We investigated how forest understory plant species composition and richness varied across gradients of acidic deposition and soil acidity in the Adirondack Mountains of New York State.

Methods We surveyed understory vegetation and soils in hardwood forests on 20 small watersheds and built models of community composition and richness as functions of soil chemistry, nitrogen and sulfur deposition, and other environmental variables.

Results Community composition varied significantly with gradients of acidic deposition, soil acidity, and base cation availability (63\% variance explained). Several species increased with soil acidity while others decreased. Understory plant richness decreased significantly with increasing soil acidity $(r=0.60)$. The best multivariate regression model to predict richness $\left(p<0.001\right.$, adjusted- $R^{2}=$ $0.60)$ reflected positive effects of $\mathrm{pH}$ and carbonto-nitrogen ratio $(\mathrm{C}: \mathrm{N})$.

Conclusions The relationship we found between understory plant communities and a soil-chemical gradient, suggests that soil acidification can reduce diversity and alter the composition of these communities in northern hardwood forests exposed to acidic deposition.

Keywords Atmospheric deposition · Plant community · Herbaceous vegetation - Northern hardwood forest · Plant diversity $\cdot$ Global change $\cdot$ Soil nutrients $\cdot$ Richness 


\section{Introduction}

Biodiversity supports beneficial ecosystem functions such as productivity, resilience, and stability, while also supporting a range of related ecosystem services (Dovciak and Halpern 2010; Cardinale et al. 2012). Wet and dry atmospheric deposition of sulfur (S) and nitrogen (N) (often referred to as "acidic deposition"), results from the combustion of fossil fuels and agricultural emissions of $\mathrm{N}$, and is a pervasive aspect of the global environmental changes that threaten vascular plant biodiversity (Schlesinger 1997; Vitousek et al. 1997; Bobbink et al. 2010). Atmospheric N and S deposition has led to increased soil acidity (primarily through inputs of $\mathrm{H}^{+}$, $\mathrm{NH}_{4}{ }^{+}, \mathrm{NO}_{3}{ }^{-}$, and $\mathrm{SO}_{4}{ }^{2-}$ ) and to enrichment of ecosystems with N, an important plant nutrient (Bobbink et al. 2010; Greaver et al. 2012). Acidification leaches other plant nutrients such as calcium $(\mathrm{Ca})$ and magnesium $(\mathrm{Mg})$ from the soil, and it mobilizes toxic aluminum (Al) (Lawrence et al. 1995; Church 1997; Driscoll et al. 2001). Plant diversity often declines with decreasing soil $\mathrm{pH}$, (Pausas and Austin 2001; Schuster and Diekmann 2003), but nutrient $(\mathrm{N})$ enrichment by atmospheric deposition can counteract diversity loss due to acidification (Simkin et al. 2016); consequently, further investigations are necessary along well-defined atmospheric deposition gradients (cf., McDonough and Watmough 2015).

Although acidic deposition in the northeastern US has declined over time as a result of air pollution control legislation (Driscoll et al. 2001; Wason et al. 2017) regional soils have shown only limited recovery as their base cations remain depleted and Al remains mobile (Lawrence et al. 2015a). The effects of historical acidic deposition were greatest in regions with areas of basepoor bedrock and till such as the Adirondack Mountains (Driscoll et al. 2001) where forest soil acidification and losses of $\mathrm{Ca}$ and other base cations have been well documented (Johnson et al. 2008; Warby et al. 2009). Acidic deposition has been implicated in declines of tree species such as red spruce (Picea rubens) (Shortle and Smith 1988; DeHayes et al. 1999) and sugar maple (Acer saccharum) (Sullivan et al. 2013b) throughout the Northeast and in the Adirondacks in particular. In contrast, the relationship between acidic deposition and forest understory plant diversity and composition - in this region and in general - is poorly understood. Yet understory plants represent the majority of plant species in temperate forests and contribute disproportionately (relative to their biomass) to net primary productivity, ecosystem nutrient cycling, food web structure, species interactions, and biodiversity (Gilliam 2007, 2014).

Although relations between acidic deposition and forest understory communities have been studied at regional (Beier et al. 2012) and continental (Simkin et al. 2016) scales in the US, results were often inconsistent. Some studies suggested that invasive species can become more abundant (Huebner et al. 2014) and native understory composition altered (Horsley et al. 2008) along soil nutrient and acidity gradients in the eastern US. Others found limited effects of $\mathrm{N}$ additions on understory vegetation and suggested that this may be due to already high historical $\mathrm{N}$ deposition levels in eastern forests (Hurd et al. 1998; Gilliam et al. 2006). Recent results from a longterm $\mathrm{N}$ addition experiment showed that species diversity and evenness responded negatively to increasing $\mathrm{N}$ (Gilliam et al. 2016). One study of northeastern forest understories found a negative relationship between species richness and $\mathrm{N}$ deposition, but this was conditional on soil $\mathrm{pH}$ and plant community type (S deposition was not considered) (Simkin et al. 2016).

Understory plants have species-specific responses to soil nutrient supply, soil acidity, moisture, and light availability (Frelich et al. 2003; Horsley et al. 2008; Bartels and Chen 2010). Interactions with these additional resources may mask the relative importance of soil drivers in affecting plant distributions (Hardtle et al. 2003; Simkin et al. 2016). For example, declining overstory tree health in response to acidic deposition (Shortle and Smith 1988; Sullivan et al. 2013b) may lead to a more open canopy and cause an increase in understory light and species richness (Pausas and Austin 2001) despite the potential negative effects of high levels of $\mathrm{N}$ or soil acidity. Moreover, small to moderate $\mathrm{N}$ additions can increase plant $\mathrm{N}$ uptake and increase species richness (Simkin et al. 2016), but larger N additions may decrease foliar concentrations of other nutrients and thus cause nutritional imbalance and stress (e.g., Ca, Mg) (Hurd et al. 1998; Bobbink et al. 2010) while favoring nitrophilic species at the expense of overall plant diversity (Gilliam 2006; Bobbink et al. 2010; Gilliam et al. 2016). Thus, evaluating the effects of atmospheric deposition and soil acidification on plant communities requires consideration of the primary drivers of species composition and richness such as light, moisture, and plant nutrients.

The goal of this study was to evaluate how large spatial gradients in acidic deposition, soil acidity, and nutrient availability relate to understory community composition and species richness while accounting for 
moisture and light availability. The study was centered in the Adirondack Park, New York, a large (approximately $24,000 \mathrm{~km}^{2}$ ) protected area where historically high rates of acidic deposition have contributed to substantial soil acidification (Johnson et al. 2008; Warby et al. 2009). Deposition levels exhibit a general decreasing gradient from west to east across the park (Ollinger et al. 1993; Ito et al. 2002; Sullivan et al. 2013b) that coincides with a gradient in the natural acid-buffering capacity of soil which tends to decrease from east to west (Beier et al. 2012; Sullivan et al. 2013b). As a result of these two factors, the impact of acidic deposition on soil acidity is likely to decrease from west to east in the park (Sullivan et al. 2013b). We surveyed 20 watersheds distributed throughout the Adirondack Park that had been studied previously to capture these gradients in acidic atmospheric deposition and associated soil acidification (Sullivan et al. 2013b; Bishop et al. 2015; Lawrence et al. 2017a). We hypothesized that, along this spatial gradient, (H1) high soil acidity and low base saturation would be associated with low understory plant species richness and community composition reflecting species tolerant of acidic soils, and (H2) acidic deposition and soil acidbase status would have stronger relationships to understory plant composition and richness at regional scales than environmental factors such as light and moisture.

\section{Methods}

Study area This study was conducted on 20 small watersheds (each $<100$ ha) within or near the boundary of the Adirondack Park in northern New York State which has experienced acidic deposition levels that have contributed to a general west to east gradient of relatively high to low soil acidity (Fig. 1; Sullivan et al. 2013b). This northern temperate forest is typified by rugged topography underlain by granitic gneisses and metasedimentary rock with widely varying mineralogy (Baker et al. 1990). Glacial scouring of this rock has left soils underlain predominantly by parent materials of coarse granitic till. Consequently, soils are commonly naturally acidic and low in base cations, a condition exacerbated by acidic atmospheric deposition (Baker et al. 1990). Soil pH and exchangeable base cations have been slow to recover from anthropogenic acidification (Lawrence et al. 2015a). Study watersheds contain northern hardwood forest dominated by American beech (Fagus grandifolia), sugar maple (Acer saccharum), and yellow birch (Betula alleghaniensis).

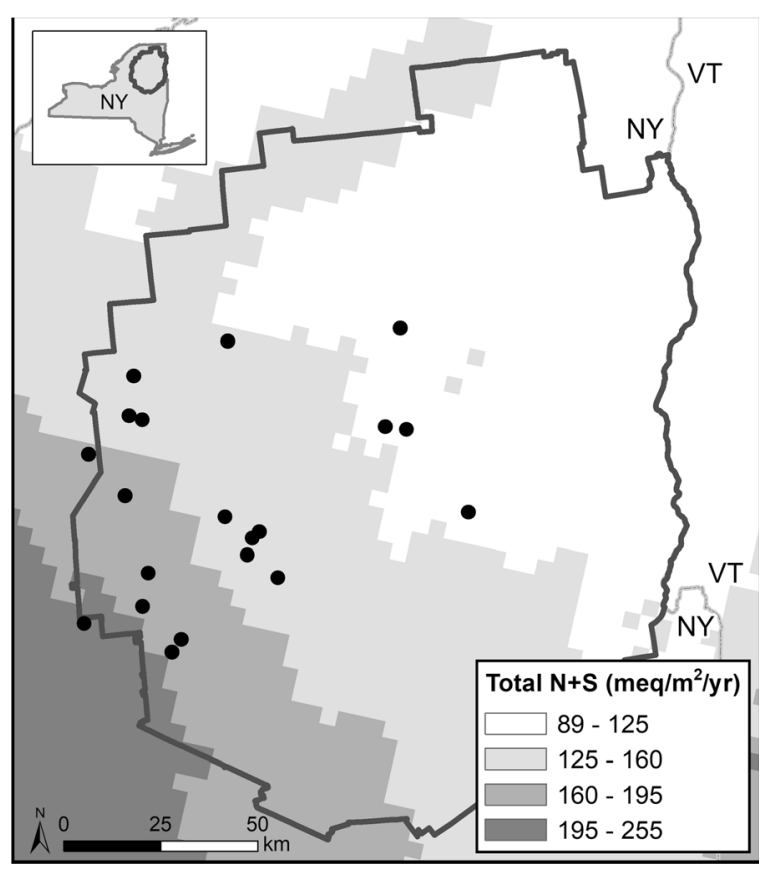

Fig. 1 Map of watershed locations (black dots, $n=20$ ) relative to the boundary of the Adirondack Park (grey outline) and deposition levels of $\mathrm{N}$ and $\mathrm{S}$ (shading). Deposition is represented by a modeled spatial gradient derived from observed $\mathrm{N}$ and $\mathrm{S}$ deposition values, averaged over the period of 2000 through 2002

Maple-beech-birch forests of the northeastern US are associated with mean daily minimum temperatures in January between -15.5 and $-7.7^{\circ} \mathrm{C}$, mean daily maximum temperatures in July between 23.3 and $26.6^{\circ} \mathrm{C}$, and mean annual precipitation ranging from 101.6 to $121.9 \mathrm{~cm}$ (McNab et al. 2007). Mean annual snowfall for this forest type is $182.9 \mathrm{~cm}$ with mean snow cover duration of 87 days; the mean annual growing season is between 120 and 150 days (McNab et al. 2007).

Site selection We returned to 20 small watersheds (Fig. 1) surveyed in 2009 for overstory composition, growth, tree recruitment, and soil chemistry (Sullivan et al. 2013b; Lawrence et al. 2017a). Fifteen of these watersheds were originally selected from a population of 200 watersheds sampled during the Western Adirondack Stream Survey (WASS). All 200 watersheds were ranked by the base cation availability of streamwater measured during WASS and stratified into 20 bins according to these rankings. After excluding those with evidence of logging within the last $\sim 40$ years or without a sufficient overstory component of $A$. saccharum, a random selection of one watershed from each bin yielded fifteen watersheds (Lawrence et al. 2008; Sullivan et al. 2013b). Since most of the selected 
watersheds contained streams that had undergone acidification, five additional watersheds (in the northeast of the region) were selected to augment the gradient of $\mathrm{Ca}$ availability (Sullivan et al. 2013b). In 2009, two or three $20 \times 50 \mathrm{~m}$ plots were established within each watershed 50 plots in total - to represent vegetation and topography typical of each watershed while including at least three large canopy sugar maples (dbh of $\geq 35 \mathrm{~cm}$ ) within each plot (Sullivan et al. 2013b).

Vegetation sampling During summer 2015, we characterized forest understory vegetation in all 50 plots within the 20 study watersheds. Within each $20 \times 50 \mathrm{~m}$ plot we established 15 subplots $(1 \times 1 \mathrm{~m})$ on a $5 \times 5 \mathrm{~m}$ grid. Subplots were marked and surveyed twice (during May-June and again during July-August) to account for variable species phenology. On each subplot, we identified to species all vascular plants $<1.5 \mathrm{~m}$ tall following Gleason and Cronquist (1991) and Holmgren (1998) using updated species nomenclature from the U.S. Department of Agriculture (USDA) Natural Resources Conservation Service (2016). For each species identified within subplots, we visually estimated percent cover of stems and foliage overlapping the subplot up to a height of $1.5 \mathrm{~m}$, following Daubenmire (1959). We also conducted a single search of the plot area outside of subplots to count all less common species in order to improve our estimates of understory species richness per plot and watershed.

Soil sampling and analyses Soil sampling was carried out in 2009 by the U.S. Geological Survey (USGS), USDA Forest Service, and E\&S Environmental Chemistry, with soil chemical analyses conducted by the USGS New York Water Science Center (see Sullivan et al. 2013a, b) for details). Mineral soils were sampled at one soil pit per plot, while organic soils were sampled with five $10 \times 10 \mathrm{~cm}$ pin blocks. All soil data are available in Lawrence et al. (2017b). Statistical analyses were performed using soil data from the $\mathrm{O}_{\mathrm{a}}$ horizon, as it occurred in nearly all plots and represented an important part of the rooting zone in these forests. In addition, the percent base saturation (BS, calculated from the sum of exchangeable base cations divided by the effective cation exchange capacity) and exchangeable bases $(\mathrm{Ca}$ and $\mathrm{Mg})$ in the upper B horizon were also considered (see Statistical Methods) because of their importance in predicting A. saccharum recruitment
(Sullivan et al. 2013b) and their utility in modeling critical deposition loads (Sullivan et al. 2011).

Acidic deposition loads Estimates of total atmospheric deposition were derived for both S and N (S-DEP and N-DEP, respectively Table 1) using the Total Deposition Project (TDEP; $4 \mathrm{~km}$ resolution) spatial model reported by Schwede and Lear (2014) and averaged over four differing time periods (see below). TDEP estimates of $\mathrm{S}$ and $\mathrm{N}$ deposition are based primarily on a combination of National Atmospheric Deposition Program (NADP) measurements of wet and dry deposition and Community Multiscale Air Quality (CMAQ) model output. We used four time frames to account for declining deposition levels relative to the dates of our soil and vegetation sampling. The first period (2006 to 2008) represented the level and pattern of deposition prior to the soil sampling. The second period (2011 to 2013) represented the deposition contacting and potentially affecting plant epidermal tissues (DeHayes et al. 1999) just prior to our vegetation sampling. The third period (2006 to 2013) represented the most recent long-term cumulative deposition patterns across our study region. The fourth period (2000 to 2002) represented a more distinct pattern of deposition over the study region characteristic of the gradient of greater deposition levels documented in the preceding decade, with deposition increasing from the northeastern corner of the Adirondacks to the southwest (Ollinger et al. 1993; Ito et al. 2002). We used ArcGIS (Esri 2018) to produce a map illustrating the spatial relationship of this pattern of deposition levels relative to our plot locations (Fig. 1). Spatial patterns of soil acidification that might have resulted from acidic deposition in our study area may have been most closely related to the 2000-2002 pattern of higher deposition than to more recent periods of lower deposition (out of the four study periods). Temporal lags of such effects on vegetation are not known.

Moisture and light indices Compound Topographic and Integrated Moisture indices (CTI and IMI, Table 1) were derived using a digital elevation model for New York State (10 m resolution) (USGS and NYS DEC 2015) following Gessler et al. (1995) and Iverson et al. (1997), respectively. The CTI is calculated by dividing the upslope (moisture contributing) area for a given point by 
Table 1 Predictor variables measured or calculated from 2009 and 2015 field measurements or remote sensing data

\begin{tabular}{|c|c|c|c|}
\hline Symbol & Units & Transformation $^{\mathrm{b}}$ & Description \\
\hline $\mathrm{pH}$ & $\mathrm{pH}$ units & Box-Cox, $-1^{\text {a }}$ & Soil Acidity ( $\mathrm{pH}$ ) Measured in Calcium Chloride \\
\hline $\mathrm{BS}^{\mathrm{a}}$ & $\%$ & - & Base Saturation \\
\hline UB BS & $\%$ & Box-Cox, -0.5 & Base Saturation in the Upper B Horizon \\
\hline Acidity $^{\mathrm{a}}$ & $\mathrm{meq} / 100 \mathrm{~g}$ & - & Exchangeable Acidity \\
\hline $\mathrm{H}^{\mathrm{a}}$ & $\mathrm{meq} / 100 \mathrm{~g}$ & - & Exchangeable $\mathrm{H}$ \\
\hline $\mathrm{Al}$ & $\mathrm{meq} / 100 \mathrm{~g}$ & Box-Cox, $0.5^{\mathrm{a}}$ & Exchangeable Aluminum \\
\hline $\mathrm{Na}$ & $\mathrm{cmol}_{\mathrm{c}} \mathrm{kg}^{-1}$ & - & Exchangeable Sodium \\
\hline $\mathrm{K}^{\mathrm{a}}$ & $\mathrm{cmol}_{\mathrm{c}} \mathrm{kg}^{-1}$ & - & Exchangeable Potassium \\
\hline $\mathrm{Ca}$ & $\mathrm{cmol}_{\mathrm{c}} \mathrm{kg}^{-1}$ & Box-Cox, -0.5 & Exchangeable Calcium \\
\hline $\mathrm{UB} \mathrm{Ca}$ & $\mathrm{cmol}_{\mathrm{c}} \mathrm{kg}^{-1}$ & Box-Cox, 0.0 & Exchangeable Calcium in the Upper B Horizon \\
\hline $\mathrm{Mg}$ & $\mathrm{cmol}_{\mathrm{c}} \mathrm{kg}^{-1}$ & Box-Cox, -0.5 & Exchangeable Magnesium \\
\hline UB Mg & $\mathrm{cmol}_{\mathrm{c}} \mathrm{kg}^{-1}$ & Box-Cox, 0.0 & Exchangeable Magnesium in the Upper B Horizon \\
\hline $\mathrm{CaMg}$ & $\mathrm{cmol}_{\mathrm{c}} \mathrm{kg}^{-1}$ & Box-Cox, $-0.5^{\mathrm{a}}$ & $\mathrm{Ca}+\mathrm{Mg}$ \\
\hline LOI & $\%$ & - & $\%$ Weight Lost on Ignition \\
\hline $\mathrm{C}$ & $\%$ & - & Total \% Carbon \\
\hline $\mathrm{N}$ & $\%$ & - & Total \% Nitrogen \\
\hline $\mathrm{C}: \mathrm{N}^{\mathrm{a}}$ & $\%$ & - & Ratio of C Divided by N (used to indicate $\mathrm{N}$ availability) \\
\hline UB N & $\%$ & - & Total \% Nitrogen in the Upper B Horizon \\
\hline S-DEPa $(01,07,12$, or 06.13$)$ & $\mathrm{kg} / \mathrm{ha} / \mathrm{yr}$ & - & $\begin{array}{l}\text { Mean Sulfur Deposition for 2000-2002 (01), 2006-2008 (07), } \\
\text { 2011-2013 (12), or 2006-2013 (06.13) from TDEP }\end{array}$ \\
\hline $\mathrm{N}-\mathrm{DEP}^{\mathrm{a}}(01,07,12$, or 06.13$)$ & $\mathrm{kg} / \mathrm{ha} / \mathrm{yr}$ & - & $\begin{array}{l}\text { Mean Nitrogen Deposition for 2000-2002 (01), 2006-2008 (07), } \\
\text { 2011-2013 (12), or 2006-2013 (06.13) from TDEP }\end{array}$ \\
\hline $\mathrm{CTI}^{\mathrm{a}}$ & - & - & Compound Topographic Index \\
\hline IMI & - & Box-Cox, $-3^{\mathrm{a}}$ & Integrated Moisture Index \\
\hline CC-GAP & $\%$ & - & $\%$ Canopy Cover from USGS-GAP \\
\hline $\mathrm{CC}-\mathrm{ES}^{\mathrm{a}}$ & $\%$ & - & \% Canopy Cover from Field Canopy Photos \\
\hline CO-D & $\%$ & - & Mean \% Canopy Openness from Densiometer \\
\hline SolRad ${ }^{\mathrm{a}}$ & - & - & Total Annual Solar Radiation from GIS Model \\
\hline Elevation $^{\mathrm{a}}$ & meters & - & From 30 m DEM (USGS 1999) \\
\hline FAGGRA-BA ${ }^{\mathrm{a}}$ & - & - & Overstory basal area proportion of Fagus grandifolia \\
\hline 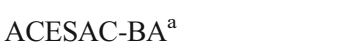 & - & - & Overstory basal area proportion of Acer saccharum \\
\hline ACERUB-BA & - & - & Overstory basal area proportion of Acer rubrum \\
\hline
\end{tabular}

Where not indicated otherwise, soil-chemical variables are from measurements taken in the $\mathrm{O}_{\mathrm{a}}$ horizon

${ }^{\text {a }}$ Variable included in regression model selection (see Statistical Methods-Species Richness Models for details)

${ }^{\mathrm{b}}$ Transformations used in OLS regression

the local slope. Higher values of CTI indicate a higher likelihood of becoming saturated with moisture (Gessler et al. 1995). The IMI also accounts for the upslope area and uses "hillshade" analysis to incorporate the extent of solar radiation in addition to local geographic curvature to account for their impact on soil moisture (Iverson et al. 1997).

We approximated the stand light environment by estimating canopy openness (CO-D, Table 1) on each plot with a convex spherical densiometer (two measurements per subplot) (Lemmon 1956). Three additional indices of plot light environment were adopted from the previous study (Sullivan et al. 2013b): (i) total annual solar radiation at ground surface (SolRad, Table 1) calculated using digital elevation models while correcting for forest canopy cover, (ii) canopy cover estimated from spectral analysis of photographs taken at each plot (CC-ES, Table 1), and (iii) canopy 
cover calculated for each plot using the USGS National Gap Analysis Program (CC-GAP, Table 1) (see Sullivan et al. 2013a, b) for details).

\section{Statistical methods}

Analyses of community composition Changes in community composition relative to environmental factors were analyzed using non-metric multidimensional scaling (NMS) in PC-ORD v. 6.19 (McCune and Mefford 2011). We characterized understory species composition in each watershed using a primary matrix representing individual species frequencies calculated as the number of $1 \times 1 \mathrm{~m}$ subplots in which a species occurred during either survey period divided by the total number of subplots in the watershed (i.e., 30 or 45 , corresponding to the number of plots per watershed). Species that occurred in two or fewer watersheds were excluded from the primary matrix to reduce the effects of rare species on the analysis (Peck 2010; McCune and Mefford 2011). This analysis captured compositional differences among watersheds based on the frequency of forest understory forbs, ferns, and woody species $(<1.5 \mathrm{~m}$ tall); graminoids were not included due to their general rarity (mean subplot cover of only $0.4 \%$, compared to $26 \%$ cover of all vascular plants) and because most graminoids occurred without flowers or fruit, making them difficult to identify to species.

Following Peck (2010) NMS was run three times on autopilot (set to slow and thorough) using Sorensen distances. Scree and stress plots suggested that a 2-dimensional solution was appropriate and NMS was then run three more times manually for two dimensions. We inspected the distribution of watersheds in the ordination space for each of the three runs to confirm solution consistency and selected the final solution using a Mantel Test (which confirmed 99.9\% redundancy between the selected and all other manual runs). Environmental variables collected on each plot were averaged to the watershed level and included in a secondary environmental matrix (Table 1); the correlations between the environmental variables and the NMS axes were calculated and plotted in the ordination space as vectors to characterize how environmental gradients across the watersheds related to differences in species composition.
Species richness models We used simple and multiple ordinary least squares (OLS) regression to analyze how species richness varied with a large number of environmental variables that included soil characteristics, understory light environment, overstory species composition, topography, and acidic deposition loads (Table 1). The regression analyses were run at the watershed level by averaging environmental variables and calculating total species richness for each of the 20 watersheds. To limit spurious results given the large variable set, the multiple regression analysis was run on the most relevant variables - those that were closely correlated with at least one of the NMS axes $\left(r \geq \pm 0.40\right.$ for soil variables from the $\mathrm{O}_{\mathrm{a}}$ horizon, and $r \geq \pm 0.20$ for other variables) (Table 2). Exchangeable $\mathrm{Ca}$ and $\mathrm{Mg}$ levels in the Oa horizon were highly correlated $(r=0.83, p<0.0001)$, had nearly identical effects on richness in multivariate regression models, and thus were combined into a single variable $(\mathrm{CaMg})$. The soil measurements total $\mathrm{N}$, total carbon (C), and loss on ignition (LOI) (Table 1) were all identified as important predictors of richness; we replaced them with a single variable, total \% soil $\mathrm{C}$-to- $\mathrm{N}$ ratio $(\mathrm{C}: \mathrm{N})$ for multiple OLS regression. Basal area of $A$. saccharum and $F$. grandifolia were also included as predictors to represent components of overstory composition that might influence soil $\mathrm{C}: \mathrm{N}$ while responding to beech bark disease and soil acidity gradients (Lovett et al. 2004; Lovett and Mitchell 2004; Lawrence et al. 2017a).

Model evaluation was carried out using $\mathrm{R}$ software and the car, leaps, and AICcmodavg packages (Lumley 2009; Fox and Weisberg 2011; Mazerolle 2016; R Development Core Team 2016). Spearman correlations among variables were calculated using the SAS University Edition (SAS Institute Inc. 2015). Variables were assessed for normality using scatterplot matrices and the Shapiro-Wilk test (non-normal at $p<0.01$ ). The symbox function was used to evaluate potential Box-Cox scaled power transformations for each variable and bcpower function to transform the variables as appropriate (see Table 1 for the specific transformations).

To avoid model overfitting given our sample size of 20 watersheds, we followed the recommendation to limit predictors to between $n / 10$ and $n / 20$ (where $n$ is the sample size) (Harrell 2015). Thus, 
Table 2 Pearson correlation coefficients (showing $r \geq \pm 0.2$ for non-soil and $r \geq \pm 0.4$ for soil variables) and coefficients of determination $\left(R^{2}\right)$ between untransformed environmental variables (Table 1) and the two NMS ordination axes across the 20 studied watersheds (Fig. 2)

\begin{tabular}{|c|c|c|}
\hline \multicolumn{3}{|l|}{ Axis 1} \\
\hline Variable & $r$ & $R^{2}$ \\
\hline $\mathrm{Mg}$ & 0.945 & 0.894 \\
\hline $\mathrm{CaMg}$ & 0.944 & 0.890 \\
\hline $\mathrm{Ca}$ & 0.939 & 0.882 \\
\hline $\mathrm{pH}$ & 0.897 & 0.804 \\
\hline BS & 0.875 & 0.766 \\
\hline UB BS & 0.744 & 0.554 \\
\hline Richness & 0.6 & 0.359 \\
\hline $\mathrm{K}$ & 0.57 & 0.325 \\
\hline ACESAC-BA & 0.544 & 0.296 \\
\hline $\mathrm{N}$ & 0.482 & 0.232 \\
\hline $\mathrm{UB} \mathrm{Ca}$ & 0.455 & 0.207 \\
\hline CC-GAP & 0.374 & 0.140 \\
\hline SolRad & 0.348 & 0.121 \\
\hline Elevation & 0.285 & 0.081 \\
\hline IMI & 0.269 & 0.073 \\
\hline CC-ES & 0.249 & 0.062 \\
\hline FAGGRA-BA & -0.327 & 0.107 \\
\hline $\mathrm{Al}$ & -0.474 & 0.225 \\
\hline S-DEP07 & -0.517 & 0.267 \\
\hline S-DEP01 & -0.573 & 0.329 \\
\hline N-DEP12 & -0.595 & 0.354 \\
\hline S-DEP06.13 & -0.632 & 0.400 \\
\hline $\mathrm{H}$ & -0.644 & 0.415 \\
\hline N-DEP07 & -0.647 & 0.419 \\
\hline ACERUB-BA & -0.648 & 0.419 \\
\hline N-DEP01 & -0.651 & 0.424 \\
\hline N-DEP06.13 & -0.678 & 0.460 \\
\hline S-DEP12 & -0.684 & 0.468 \\
\hline Acidity & -0.686 & 0.470 \\
\hline $\mathrm{C}: \mathrm{N}$ & -0.738 & 0.545 \\
\hline \multicolumn{3}{|l|}{ Axis 2} \\
\hline Variable & $r$ & $R^{2}$ \\
\hline Elevation & -0.652 & 0.425 \\
\hline $\mathrm{C}$ & -0.626 & 0.392 \\
\hline CC-ES & -0.499 & 0.249 \\
\hline LOI & -0.474 & 0.225 \\
\hline FAGGRA-BA & -0.46 & 0.212 \\
\hline UB N & -0.406 & 0.165 \\
\hline CC-GAP & -0.351 & 0.123 \\
\hline ACERUB-BA & 0.205 & 0.042 \\
\hline IMI & 0.273 & 0.074 \\
\hline S-DEP01 & 0.28 & 0.078 \\
\hline N-DEP06.13 & 0.284 & 0.081 \\
\hline N-DEP01 & 0.319 & 0.102 \\
\hline CTI & 0.355 & 0.126 \\
\hline N-DEP07 & 0.378 & 0.143 \\
\hline ACESAC-BA & 0.384 & 0.147 \\
\hline
\end{tabular}

the final models were limited to one or two predictor variable combinations that were selected as follows. First, we constructed four models from the same set of 16 potential predictors (Table 1) by adding a different pair of deposition ( $\mathrm{N}$ and $\mathrm{S}$ ) variables in each model (i.e., each of these four models used a different time period for N-DEP and S-DEP from the four periods available; Table 1). Then, we used the regsubsets function in $\mathrm{R}$ to search (set to exhaustive) for the five best (nbest $=5)$ two- or one-predictor candidate models $($ nvmax $=2)$ reduced from each of the four original models in two selection runs. One run ranked candidate models by Schwarz's Information Criterion (BIC), a measure of model parsimony similar to Akaike's Information Criterion (AIC), and another by adjusted- $R^{2}$ (Schwarz 1978; Shurin et al. 2010; Purse et al. 2012; Horrigue et al. 2016). The top three candidate models from each run were then ranked using AIC adjusted for small sample size $(A I C c)$ to determine the best final models (Purse et al. 2012).

The final candidate models were assessed for collinearity using the VIF function, heteroscedasticity using the functions ncvTest and residualPlots, outliers using the functions outlierTest, influenceIndexPlot, and qqPlot, model fit using the function marginalModelPlot, and the effects of individual predictors on species richness using the function avPlots (Fox and Weisberg 2011). Results of diagnostic tests showed acceptable levels of collinearity based on variance inflation factors $(\mathrm{VIF}<2.22)$, and heteroscedasticity based on a plot of Pearson's residuals against fitted values and a negative Breusch-Pagan test (Fox and Weisberg 2011).

Finally, we compared the effects of individual soil predictors (measured in the $\mathrm{O}_{\mathrm{a}}$ horizon) identified in the best richness models with the effects of the same soil variables measured in the upper B horizon using simple regressions to verify if the use of a particular soil horizon might have affected our results and inferences. In addition, we regressed richness specifically against BS (in the Oa and upper B horizons) because BS was highly correlated to some of the best predictors and has been identified as an important predictor of vegetative responses to soil acidification (Sullivan et al. 2013b). 


\section{Results}

Trends in community composition across environmental gradients Community composition varied along two distinct gradients as implied by the NMS analysis (randomization test $p=0.002$; stress $=11.23$, well under a maximum interpretable stress threshold of 20; Horsley et al. 2008; Peck 2010) (Fig. 2). NMS axis 1 represented $63.3 \%$ of variation in species composition along a gradient of soil buffering capacity, acidity, and acidic atmospheric deposition: NMS axis 1 was strongly and positively correlated with $\mathrm{pH}, \mathrm{BS}$ and plant nutrient cations (e.g., $\mathrm{Mg}, r=0.945)$, and negatively with acidic deposition (e.g., N-DEP01, $r=-0.651$ ) and variables indicative of soil acidity and potentially of soil acidification (e.g., exchangeable Al, $r=-0.474$ ) (Fig. 2, Table 2). NMS axis 2 represented $27.8 \%$ of the variation in species composition along gradients of soil organic matter (C, LOI), canopy cover (CC-ES), and elevation variables negatively correlated with axis 2 (e.g., $\mathrm{C}, r=$ -0.626) (Fig. 2, Table 2).

The ordination also described a gradient in species richness that corresponded with the gradient in acidic deposition, soil acidity, and nutrient availability represented by axis 1 (Fig. 2). Richness was positively correlated with axis $1(r=0.600)$ and was positively associated with soil $\mathrm{pH}$ and base cation availability and negatively associated with acidic deposition and soil acidity (Fig. 2, Table 2). Eight species were strongly positively correlated with axis $1(r \geq 0.4)$ as they were more common on watersheds with higher $\mathrm{pH}$ and exchangeable base cations. Only four species were negatively correlated with this axis $(r \leq-0.4)$ as they were more common on watersheds exposed to higher acidic deposition loads and with higher soil acidity (Table 3, Fig. 3). Nine species were positively correlated with axis $2(r \geq 0.4)$, while three species were negatively correlated with it $(r \leq-0.4)$, reflecting species negative or positive associations with higher canopy cover, soil organic matter, and elevation (Table 3, Fig. 3).

Environmental drivers of species richness Species richness across watersheds was predicted best by a twovariable model (adjusted- $R^{2}=0.60, p$-value $<0.001$ ) with positive effects of $\mathrm{pH}$ and $\mathrm{C}: \mathrm{N}$ ratio (Table 4 , Fig. 4). The next three alternative models for predicting species richness were equivalent to the first model statistically $(\triangle \mathrm{AICc}<2$; Table 4$)$ and in part ecologically. Although $\mathrm{C}: \mathrm{N}$ was dropped from these models, either

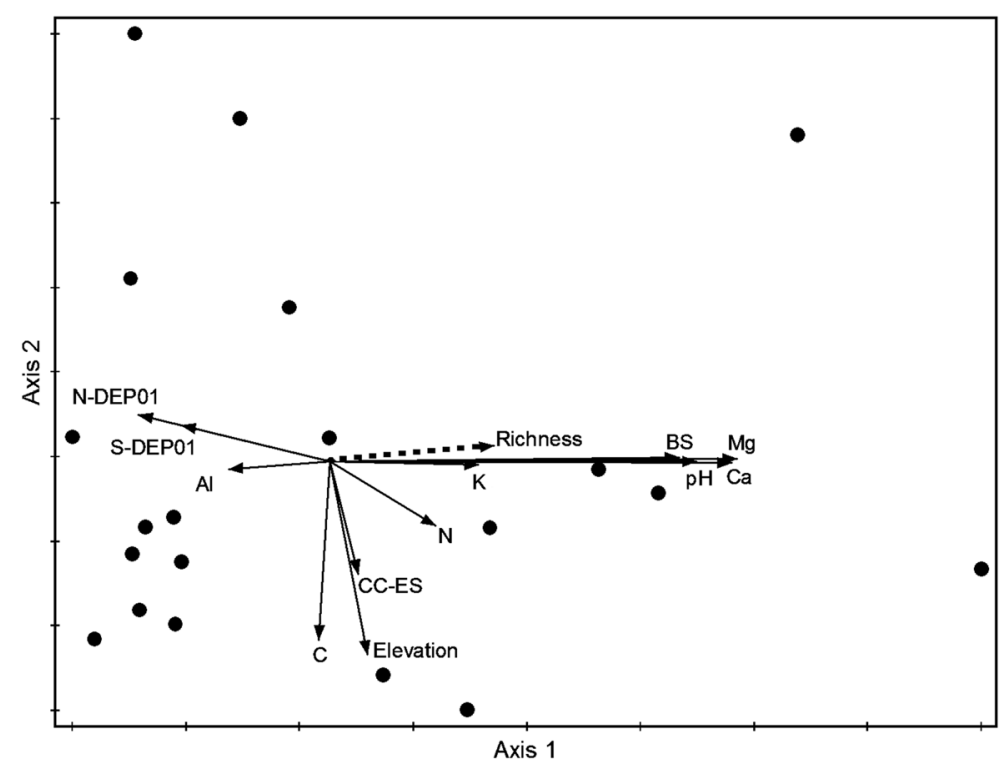

Fig. 2 Trends in species composition across the 20 studied watersheds (filled circles) depicted using NMS ordination. Watersheds that are further apart within the ordination space are more dissimilar in their species composition, while watersheds that are close to each other are more similar. Vectors show correlations between the NMS axes and (a) species richness (dashed arrow) and (b) key environmental variables (solid arrows), scaled in proportion to correlation coefficient; all vectors have $r \geq \pm 0.4$ and $R^{2} \geq \pm 0.2$ with at least one axis (Table 2). See Table 1 for abbreviations and units for the environmental variables (vectors) 
Table 3 Pearson correlations between understory species and the two NMS ordination axes from 20 studied watersheds (Fig. 3)

\begin{tabular}{|c|c|c|c|}
\hline Genus \& Species & Code & $r$ & $R^{2}$ \\
\hline \multicolumn{4}{|l|}{ Axis 1} \\
\hline Dryopteris intermedia & DRYINT & -0.857 & 0.735 \\
\hline Acer pennsylvanicum & ACEPEN & -0.744 & 0.553 \\
\hline Acer rubrum & ACERUB & -0.684 & 0.467 \\
\hline Dennstaedtia punctilobula & DENPUN & -0.533 & 0.284 \\
\hline Viola renifolia & VIOREN & 0.469 & 0.220 \\
\hline Polystichum acrostichoides & POLACR & 0.510 & 0.260 \\
\hline Tiarella cordifolia & TIACOR & 0.515 & 0.265 \\
\hline Polygonatum pubescens & POLPUB & 0.560 & 0.314 \\
\hline Acer saccharum & ACESAC & 0.717 & 0.514 \\
\hline Fraxinus americana & FRAAME & 0.751 & 0.563 \\
\hline Ostrya virginiana & OSTVIR & 0.754 & 0.569 \\
\hline Arisaema triphyllum & ARITRI & 0.829 & 0.688 \\
\hline \multicolumn{4}{|l|}{ Axis 2} \\
\hline Huperzia lucidula & HUPLUC & -0.697 & 0.486 \\
\hline Fagus grandifolia & FAGGRA & -0.461 & 0.213 \\
\hline Acer pennsylvanicum & ACEPEN & -0.448 & 0.201 \\
\hline Polygonatum pubescens & POLPUB & 0.456 & 0.208 \\
\hline Rubus allegheniensis & RUBALL & 0.525 & 0.275 \\
\hline Uvularia sessifolia & UVUSES & 0.538 & 0.289 \\
\hline Maianthemum racemosa & MAIRAC & 0.539 & 0.291 \\
\hline Dennstaedtia punctilobula & DENPUN & 0.574 & 0.330 \\
\hline Prunus serotina & PRUSER & 0.600 & 0.360 \\
\hline Aralia nudicaulis & ARANUD & 0.609 & 0.371 \\
\hline Maianthemum canadense & MAICAN & 0.690 & 0.476 \\
\hline Dendrolycopodium dendroidium & DENDEN & 0.691 & 0.477 \\
\hline
\end{tabular}

Only species with the strongest Pearson correlation coefficients $(r \geq \pm 0.4)$ and fits $\left(R^{2} \geq 0.2\right)$ with at least one of the two NMS ordination axes are shown

$\mathrm{pH}$ or $\mathrm{CaMg}$ was retained as a statistically significant predictor of richness (at $\alpha=0.05$; with model adjusted$R^{2}$ ranging from 0.52 to 0.58 and model $p$-values $<0.001)$. Soil $\mathrm{Ca}, \mathrm{pH}$, and $\mathrm{Mg}$ were all highly correlated (Spearman $r>0.838$ ) and these variables were the most prominent and statistically significant predictors across all potentially equivalent alternative models $(\triangle \mathrm{AICc}<$ 4) (Table 4). The dramatic positive effects of bases (BS, exchangeable $\mathrm{Ca}$ and $\mathrm{Mg}$ ) on species richness were similar in both soil horizons (Fig. 5). Interestingly, $\mathrm{Mg}$ and $\mathrm{Ca}$ in the Oa horizon were equally closely related to richness, but $\mathrm{Mg}$ was less closely linked to richness than $\mathrm{Ca}$ in the upper B horizon (Fig. 5).
While the best models of species richness included strong effects of $\mathrm{pH}$ or base cations, all of these soil variables described a composite soil and acidic deposition gradient (cf., axis 1, Fig. 2) where the individual soil and deposition variables co-varied with each other as expected. For example, $\mathrm{pH}, \mathrm{Mg}, \mathrm{Ca}$, potassium $(\mathrm{K})$, and $\mathrm{BS}$ had generally strong positive Spearman correlations with each other and with species richness $(r=0.44$ to $0.93, p<0.05)$. Exchangeable $\mathrm{H}$ and acidity were positively correlated with each other ( $r=0.87, p<0.0001)$, but they were negatively correlated with $\mathrm{pH}, \mathrm{Mg}, \mathrm{Ca}, \mathrm{BS}$ in the Oa horizon, and with species richness $(r=-0.85$ to -0.53 , $p<0.05)$. Exchangeable Al was positively correlated with exchangeable acidity $(r=0.65, p<0.01)$ and negatively with species richness, $\mathrm{BS}, \mathrm{Ca}$, and $\mathrm{Mg}(r=-0.48$ to $-0.70, p<0.05)$. Acidic atmospheric deposition (both N-DEP07 and S-DEP07) had strong positive correlations with exchangeable acidity and $\mathrm{H}(r=0.66$ to $0.73, p<0.01)$ and strong negative correlations with $\mathrm{Ca}, \mathrm{Mg}, \mathrm{pH}$, and $\mathrm{BS}$ $(r=-0.60$ to $-0.83, p \leq 0.01)$. Both N-DEP07 and S-DEP07 were negatively correlated with species richness $(r=-0.64$ and -0.51 respectively, $p \leq$ $0.05)$. The relationships among soil and deposition variables and richness (Table 5) were corroborated by the NMS analysis and regressions across both soil horizons (Table 2, Figs. 2 and 5).

\section{Discussion}

Our results provide evidence that the strong gradients in soil $\mathrm{pH}$ and base cation availability across Adirondack hardwood forests shape understory plant community composition and richness (Fig. 2). The gradient in soil acidity that we documented across our study watersheds coincides with strong and well-documented atmospheric deposition gradients of S and N (Ollinger et al. 1993; Ito et al. 2002; Sullivan et al. 2013b) that likely enhanced any natural soil acidity gradients by depleting bases in poorly buffered soils (cf., Warby et al. 2009). $\mathrm{Up}$ to $30 \%$ of $\mathrm{Ca}$ lost from forest soils in the Adirondacks between 1984 and 2004 was attributed to leaching by $\mathrm{SO}_{4}{ }^{2-}$ deposition (Johnson et al. 2008). A study of soil acidification across 54 sites in the Adirondacks found a $78 \%$ decrease in mean $\mathrm{Ca}$ 
Fig. 3 Effects of understory species distributions on the ordination described in Fig. 2. Centroids (filled triangles) describe average species scores on the two NMS axes relative to watershed scores (filled circles). Species most correlated with at least one of the axes $(r \geq \pm 0.4)$ $\left(R^{2} \geq 0.20\right)$ are labeled with species codes (see Table 3 )

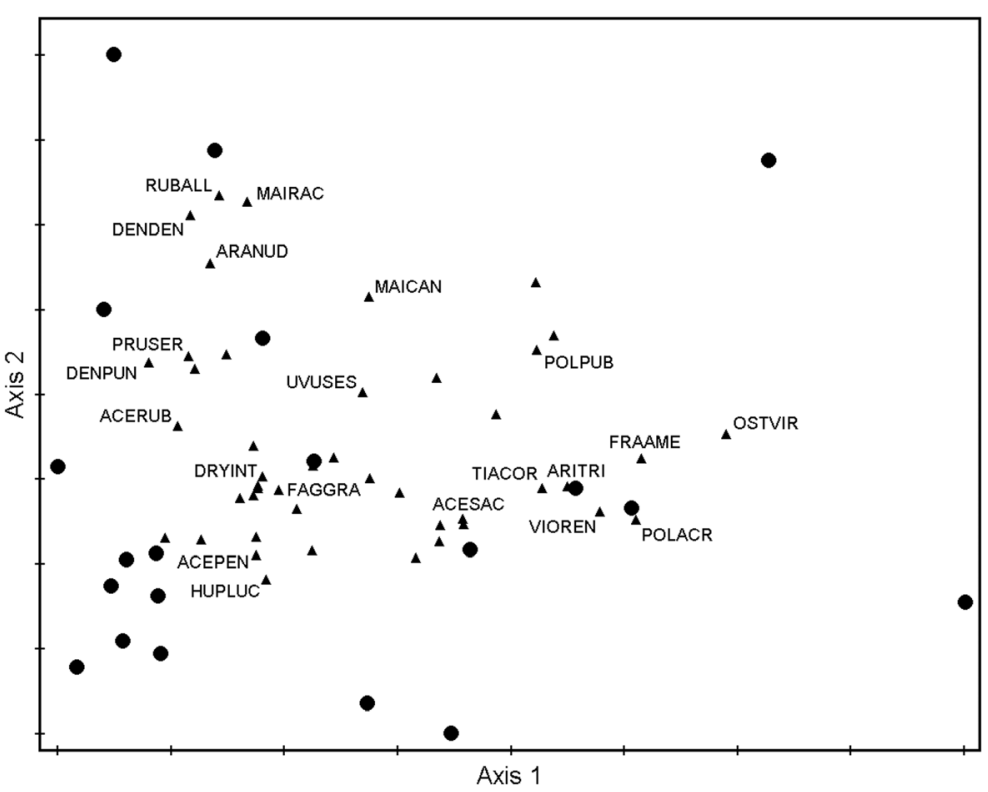

concentrations within the organic horizons of several forest types between 1932 and 2005/06 (Bedison and Johnson 2010). Declines in Ca of similar magnitude were found in forests across northern New England between 1984 and 2001 (Warby et al. 2009).

Coincidentally, our spatial gradient in soil characteristics represents a $78 \%$ difference between the means of the five highest and five lowest watershed $\mathrm{Ca}$ concentrations (cf., Table 5). In addition to $\mathrm{Ca}$, soil acidification in the northeastern US has decreased soil $\mathrm{pH}$ and other exchangeable base cations like $\mathrm{Mg}$, while mobilizing $\mathrm{Al}$ (Lawrence et al. 1995; Driscoll et al. 2001; Warby et al.
2009). Consequently, soil-chemical variables (e.g., reduced $\mathrm{pH}$ or base cation availability) are likely to be better predictors of long-term acidic deposition impacts on forest understory plant communities than the deposition variables themselves since soils acidify over time in response to cumulative acidic deposition inputs (van Dobben and de Vries 2010) and changes in the chemistry of regional soils have persisted even as acidic deposition has declined (Lawrence et al. 2015a).

Although soils across our study area have been acidified (Johnson et al. 2008; Warby et al. 2009), we found no evidence that $\mathrm{N}$ deposition led to $\mathrm{N}$ accumulation in

Table 4 The top models $\left(\Delta \mathrm{AIC}_{\mathrm{c}}<4\right)$ of species richness across the 20 studied watersheds

\begin{tabular}{|c|c|c|c|c|c|c|}
\hline \multirow[b]{2}{*}{ Model Rank } & \multicolumn{3}{|c|}{ Coefficient Estimates $^{\mathrm{a}}$} & \multicolumn{3}{|c|}{ Model Statistics } \\
\hline & $\mathrm{pH}$ & $\mathrm{CaMg}$ & $\mathrm{C}: \mathrm{N}$ & $\Delta \mathrm{AIC}_{\mathrm{c}}^{\mathrm{b}}$ & Adjusted- $R^{2}$ & Model $p$-value \\
\hline 1 & $268.42^{* * * *}$ & - & $3.13^{*}$ & 0 & 0.60 & 0.00013 \\
\hline $2^{\mathrm{c}}$ & - & $66.87^{\text {**** }}$ & - & 1.30 & 0.58 & 0.00022 \\
\hline $3^{c}$ & $240.89^{* * * *}$ & - & - & 1.32 & 0.58 & 0.00022 \\
\hline 4 & $182.31^{* * *}$ & - & - & 1.87 & 0.52 & 0.00017 \\
\hline 5 & - & $50.03^{* * *}$ & - & 2.03 & 0.52 & 0.00019 \\
\hline 6 & - & $65.09^{* * * *}$ & 2.14 & 2.6 & 0.55 & 0.00039 \\
\hline $7^{\mathrm{c}}$ & $227.07^{* * *}$ & - & - & 3.46 & 0.53 & 0.00056 \\
\hline $8^{\mathrm{c}}$ & $195.43^{* * *}$ & - & - & 3.56 & 0.53 & 0.00059 \\
\hline
\end{tabular}

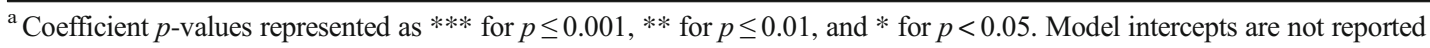

${ }^{\mathrm{b}}$ Change $(\Delta)$ in $\mathrm{AIC}_{\mathrm{c}}$ relative to the best model

${ }^{\mathrm{c}}$ Model includes one additional, statistically non-significant $(P>0.05)$ term selected by $\triangle \mathrm{AIC}_{\mathrm{c}}$ criterion: S-DEP12 (models 2 and 3 ), NDEP06.13 (model 7), or CC-ES (model 8) 

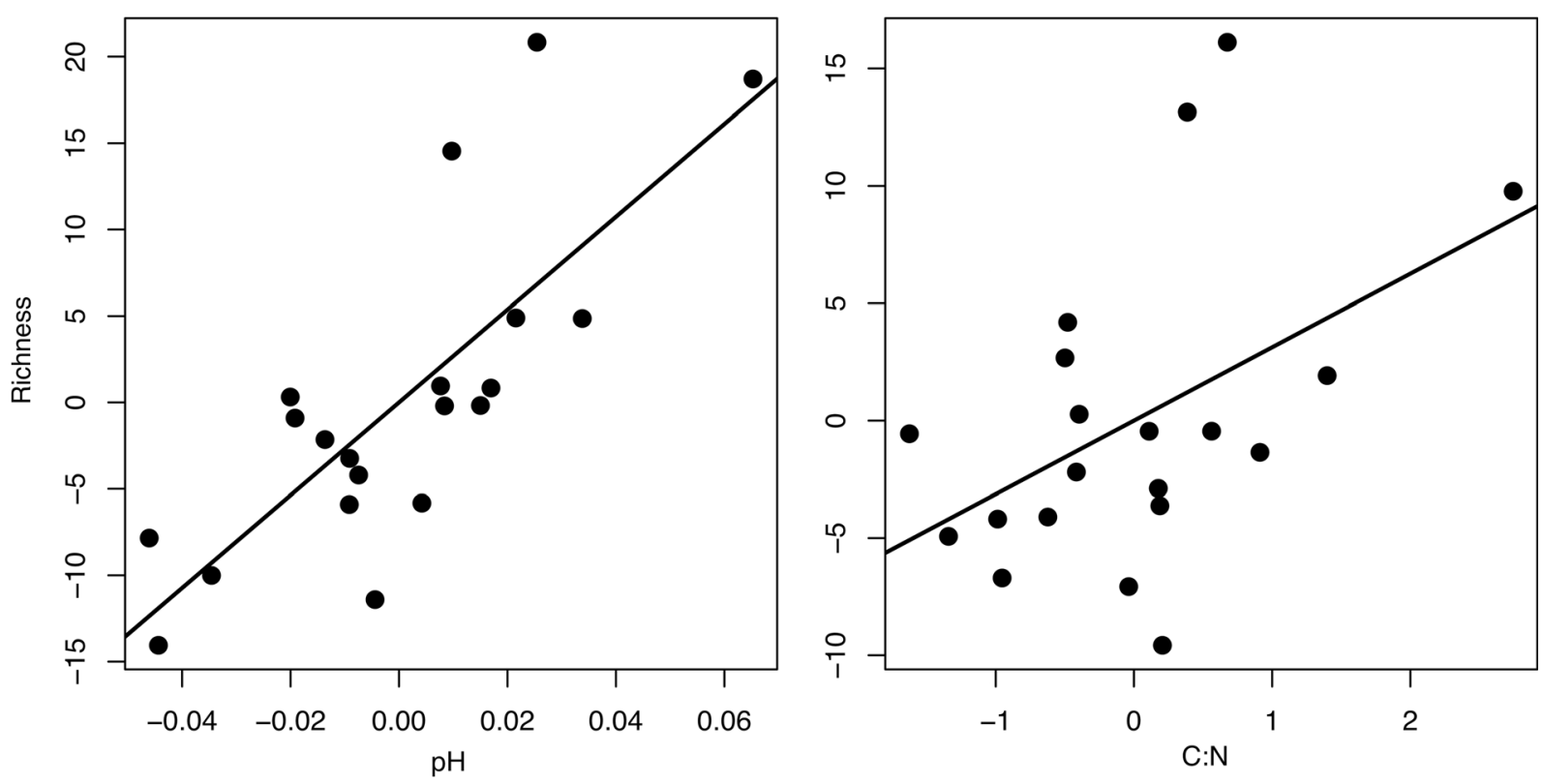

Fig. 4 The best multiple regression model for predicting species richness, displayed as added variable plots, showing the effects of each predictor when the second is held constant. Table 4 provides model coefficients and $p$-values

the $\mathrm{O}_{\mathrm{a}}$ soil horizon (Driscoll et al. 2001). We observed a negative relationship between total \% soil $\mathrm{N}$ and $\mathrm{N}$ deposition (cf., Fig. 2), likely due to the complex nature of the effects of acidic deposition on vegetation and nitrogen cycling. For example, acidic deposition can cause reduced recruitment and health of overstory trees (Sullivan et al. 2013b), and particularly so for A. saccharum; this may cause increasing soil C:N ratios (Lovett and Mitchell 2004). Additional analyses (not reported here) suggested that variation in $\mathrm{C}: \mathrm{N}$ across our sites was influenced by both soil $\mathrm{pH}$ and overstory composition - each known to be sensitive to acidic deposition (Lawrence et al. 2017a). While overstory species composition can influence forest floor C:N ratios, $\mathrm{N}$ mineralization, and leaching (Lovett and Mitchell 2004; Lovett et al. 2004), declines in overstory growth (Bishop et al. 2015) and understory vegetation (Hurd et al. 1998; Simkin et al. 2016) may reduce biological $\mathrm{N}$ uptake and result in greater $\mathrm{N}$ losses by leaching.

Understory community composition in our study varied with base cation availability, soil $\mathrm{pH}$, and acidic deposition, findings consistent with previous work showing a positive relationship between BS and tree seedling recruitment for A. saccharum (Sullivan et al. 2013b). We also observed that seedlings of other tree species, Ostrya virginiana and Fraxinus americana, were positively associated with $\mathrm{pH}$ and base cation availability (Fig. 3, Table 3), while tree seedlings for Acer rubrum and Acer pensylvanicum were associated with acidified soils. Importantly, we observed a close coupling of soil exchangeable $\mathrm{Ca}, \mathrm{Mg}$, and soil $\mathrm{pH}$ conditions with herbaceous community composition, corroborating and adding new information to other studies in northern hardwood forests (Horsley et al. 2008; McDonough and Watmough 2015). Specifically, we found that four herbaceous species were positively associated with $\mathrm{pH}$ and base cation availability (Arisaema triphyllum, Tiarella cordifolia, Polygonatum pubescens, and Polystichum acrostichoides; Fig. 3, Table 3) (cf., Horsley et al. 2008; Lawrence et al. 2015b) while two herbaceous species (Dennstaedtia punctilobula and Dryopteris intermedia) were associated with acidic soils (cf., Lawrence et al. 2015b; Gilliam et al. 2016)). In other studies, D. punctilobula and Rubus allegheniensis were found to respond positively to both experimental $\mathrm{N}$ addition (Gilliam et al. 2016), and to increased canopy openness (Hill and Silander 2001; Gilliam et al. 2016), which may arise from the decline of A. saccharum triggered by acidic deposition (Sullivan et al. 2013b; Lawrence et al. 2017a). Indeed, each of these species was positively associated with light availability in our study (Fig. 3, Table 3).

The documented variation in forest understory composition and decreasing species richness along a spatial gradient in acidic deposition and soil 

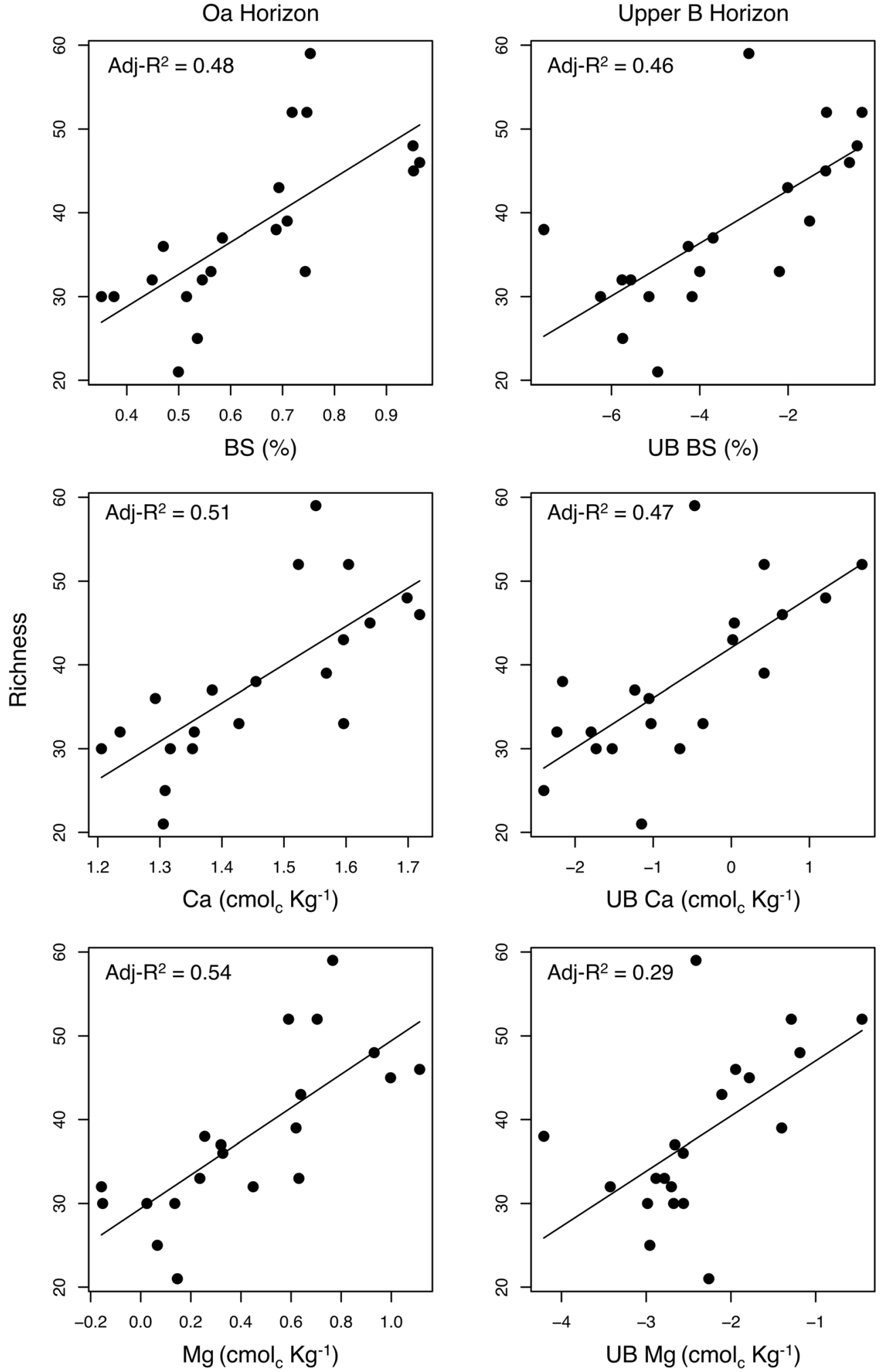

Fig. 5 Relationship of species richness with the soil variables characterizing base saturation and base cation $(\mathrm{Ca}, \mathrm{Mg})$ concentrations in the $\mathrm{Oa}$ (left column) and Upper B (right column)

horizons across the 20 study watersheds. Simple regression fits and model summaries (adjusted- $R^{2}$ ) shown. See Table 1 for variable transformations 
Table 5 Watershed-level values of variables describing the spatial gradient in soil chemistry (Ca, BS, pH, C:N), acidic deposition (Total $\mathrm{N}+\mathrm{S}$ ), forest composition (ACESAC-BA), and understory plant species richness

\begin{tabular}{|c|c|c|c|c|c|c|c|}
\hline Watershed ID & $\mathrm{Ca}$ & $\mathrm{BS}$ & $\mathrm{pH}$ & $\mathrm{C}: \mathrm{N}$ & Total $\mathrm{N}+\mathrm{S}$ & ACESAC-BA & Richness \\
\hline S14 & 50.527 & 0.964 & 4.566 & 15.357 & 122.835 & 0.657 & 46 \\
\hline 24001 & 43.981 & 0.951 & 4.296 & 16.273 & 147.907 & 0.899 & 48 \\
\hline NW & 30.624 & 0.952 & 4.197 & 15.855 & 121.879 & 0.645 & 45 \\
\hline 28030 & 25.516 & 0.718 & 3.390 & 18.786 & 150.707 & 0.626 & 52 \\
\hline AMP & 24.524 & 0.744 & 3.469 & 18.180 & 115.514 & 0.584 & 33 \\
\hline WF & 24.494 & 0.693 & 3.776 & 18.483 & 151.213 & 0.647 & 43 \\
\hline N1 & 21.467 & 0.709 & 3.646 & 18.020 & 123.037 & 0.687 & 39 \\
\hline 7001 & 19.872 & 0.753 & 3.665 & 18.468 & 141.574 & 0.578 & 59 \\
\hline 28037 & 17.599 & 0.747 & 3.617 & 20.636 & 149.719 & 0.506 & 52 \\
\hline 17002 & 13.459 & 0.688 & 3.099 & 18.683 & 168.664 & 0.701 & 38 \\
\hline 12003 & 12.199 & 0.562 & 3.081 & 19.326 & 151.720 & 0.583 & 33 \\
\hline 9006 & 10.553 & 0.584 & 3.127 & 18.585 & 126.343 & 0.391 & 37 \\
\hline 29012 & 9.629 & 0.545 & 3.035 & 17.726 & 201.976 & 0.748 & 32 \\
\hline 22019 & 9.543 & 0.515 & 3.052 & 19.478 & 176.848 & 0.440 & 30 \\
\hline 26008 & 8.571 & 0.351 & 3.159 & 17.652 & 183.230 & 0.558 & 30 \\
\hline 13008 & 8.364 & 0.536 & 3.140 & 19.253 & 150.316 & 0.542 & 25 \\
\hline 35014 & 8.295 & 0.499 & 2.700 & 19.853 & 189.447 & 0.396 & 21 \\
\hline 27019 & 7.997 & 0.470 & 3.204 & 18.476 & 151.940 & 0.380 & 36 \\
\hline 30009 & 6.851 & 0.449 & 2.915 & 21.123 & 189.005 & 0.443 & 32 \\
\hline 31009 & 6.343 & 0.375 & 2.932 & 20.231 & 181.473 & 0.324 & 30 \\
\hline
\end{tabular}

Watersheds are sorted by decreasing concentration of exchangeable $\mathrm{Ca}\left(\mathrm{cmol}_{\mathrm{c}} \mathrm{kg}^{-1}\right)$. Total $\mathrm{N}+\mathrm{S}\left(\mathrm{meq} / \mathrm{m}^{2} / \mathrm{yr}\right)$ is a modeled 3-year average centered on 2001. See Table 1 for other abbreviations and units

chemistry is a trend rarely documented in the northern hardwood forests of North America. Previous work in the Adirondacks found no relationship between understory richness and a gradient of soil $\mathrm{Ca}$, probably as a result of a smaller sample size (Beier et al. 2012). A study in sugar maple-dominated forests in southeast Ontario, Canada, found that herbaceous species richness was closely related to gradients in both climate and $\mathrm{pH}$. The authors suggested that studies which isolate acidic deposition gradients from other environmental gradients (such as climate) may be needed to discern the effects of acidic deposition on forest herbaceous plant communities (McDonough and Watmough 2015). Furthermore, in large continental-scale studies that include multiple plant community types, the more subtle relationship between understory plant richness and acidic deposition or soil acidification variables may be masked or diluted by the broad environmental gradients (e.g., climate, soil characteristics, or overstory composition) captured (van Dobben and de Vries
2010). The dominant gradients captured in our study were those of acidic deposition, soil acidity, and base cation availability.

We limited natural variation in plant community composition by establishing plots in northern hardwood forest with overstories dominated by A. saccharum (cf., Table 5). Previous investigations of these watersheds have documented a near absence of regeneration by this species in forest understories on base-poor plots (cf., Sullivan et al. 2013b; Lawrence et al. 2017a). This mismatch between the abundance of $A$. saccharum in the overstory and its lack of regeneration in the understory on acidic soils suggests that these soils must have been acidified in the time since those mature trees became established. Such acidification would explain a resulting decline in A. saccharum seedlings on currently acidic plots (Sullivan et al. 2013b). Understory species requiring high soil base cation content would likely also have declined (cf., Horsley et al. 2008).

Not only did we find that soil $\mathrm{pH}$ and base cation availability $(\mathrm{Ca}, \mathrm{Mg})$ were equally strong predictors of 
species richness, they were also significantly stronger predictors than any other variable (cf., Table 1). Compared to overstory species, little research has been conducted on the impacts of $\mathrm{Mg}$ or Ca leaching from forest soils on understory plants. Vigor and growth of A. saccharum (Sullivan et al. 2013b; Bishop et al. 2015) and cold tolerance of $P$. rubens (DeHayes et al. 1999) have been shown to be negatively associated with low soil exchangeable $\mathrm{Ca}$, but we are not aware of any such research on forest understory plants. However, $\mathrm{Ca}$ is generally important in plant internal signaling and structures such as cell walls, membranes, and stomata (McLaughlin and Wimmer 1999). Calcium deficiency can cause weaker plant responses to injury and infection, impaired growth, and inefficient gas exchange and water use (McLaughlin and Wimmer 1999). Magnesium also plays an important role in plant ecophysiology; it is a key element in photosynthesis and it can counter Al toxicity on acidified soils (Chen and Ma 2013). Magnesium deficiency can reduce photosynthesis, protein synthesis, root growth, and starch storage (Shaul 2002), and it was identified as one of the potential mechanisms for well-documented declines of A. saccharum in the northeastern US (Horsley et al. 2000). Nutritional stress in forest plants will likely be exacerbated by the effects of increasing pests, disease, and extreme weather events associated with changing climate (cf., Romero-Lankao et al. 2014), a combination that could further diminish forest plant diversity.

$\mathrm{N}$ deposition has been associated with varying impacts on forest understory communities depending on site characteristics including climate, soil $\mathrm{pH}$, and $\mathrm{cu}-$ mulative deposition load (Hurd et al. 1998; Gilliam et al. 2006; Bobbink et al. 2010; Simkin et al. 2016). We found that species richness was related negatively to $\mathrm{N}$ (positively to C:N ratio - a proxy for plant-available $\mathrm{N}$ (Janssen 1996)), but this relationship was weaker than the relationship between species richness and $\mathrm{pH}$ or base cations. Out of several investigations of $\mathrm{N}$ deposition impacts on forest understory plant communities in the eastern US (Hurd et al. 1998; Rainey et al. 1999; Gilliam et al. 2006), few found links between $\mathrm{N}$ deposition and diversity and evenness (Gilliam et al. 2016), or species richness (Simkin et al. 2016) as we did. There are several mechanisms by which nitrogen enrichment might impact understory plant richness. Nitrogen enrichment may decrease mycorrhizal associations, leaving plants vulnerable to pathogens and droughts, while increased foliar $\mathrm{N}$ may increase herbivory (Gilliam
2006). High soil nitrogen may cause declines in species richness as communities become dominated by a few nitrophilic species (Gilliam 2006; Bobbink et al. 2010; Gilliam et al. 2016). However, our results support the idea that $\mathrm{N}$ enrichment in closed canopy forests in the Adirondack region affects understory plant species richness less so than does soil acidification and base cation leaching (cf., Simkin et al. 2016).

\section{Conclusions}

This study has linked historical patterns of $\mathrm{N}$ and $\mathrm{S}$ deposition and distinct regional gradients in soil acidity and base saturation in the Adirondack ecoregion to patterns of understory plant species composition and richness in hardwood forests. Forest understory plant community composition varied and richness decreased along a spatial gradient of decreasing $\mathrm{pH}$ and soil base saturation $(\mathrm{Ca}$ and $\mathrm{Mg}$ ). Plant-available soil nitrogen was negatively related to species richness (positive relationship between $\mathrm{C}: \mathrm{N}$ ratio and richness), although the linkage between soil $\mathrm{N}$ and $\mathrm{N}$ deposition was not clear and warrants further study. In contrast, there was little relation between plant understory communities and other variables such as light and moisture at the watershed level. The ongoing decline in acidic atmospheric deposition over time has resulted in little recovery of forest soils to date (Lawrence et al. 2015a) and we documented probable biological legacies of soil acidification in terms of plant diversity loss and community change.

The spatial differences in plant community composition and diversity captured in our study should parallel the changes that a similar ecosystem would experience across time were its soils to acidify by a magnitude comparable to the acidity gradient captured in our study (cf., Table 5). Substitutions of spatial environmental gradients for environmental change over time (i.e., space for time substitution) are not perfect, but they can help us understand potential impacts of soil acidification where historical vegetation data are not available prior to the start of acidic deposition. However, such analyses require care since their validity can be undermined if the magnitude of the expected environmental change over time is much smaller than a studied spatial gradient (Blois et al. 2013). In our case, we think that our studied spatial gradient was a reasonable proxy for the magnitude of soil acidification documented for the region due to acidic deposition. Thus, soil 
acidification and associated declines in forest biodiversity have likely exacerbated widely documented declines in global biodiversity (Parmesan 2006; Bobbink et al. 2010) in regions with a history of intense acidic deposition. Since biodiversity can affect ecosystem functioning and stability (Dovciak and Halpern 2010; Cardinale et al. 2012), the loss of plant diversity may lead to a decline of forest ecosystem functions and leave these systems vulnerable to other aspects of global environmental change (e.g., climate) in regions with acidified soils.

Acknowledgements This work was supported by a contract (no. 50773) between the New York State Energy Research and Development Authority (NYSERDA) and E\&S Environmental Chemistry, Inc., under the direction of Gregory Lampman. We acknowledge the New York State Department of Environmental Conservation for permits for fieldwork in the Adirondack Park. The Adirondack Ecological Center in Newcomb and Ranger School in Wanakena (both SUNY-ESF) provided field housing and logistical support. Jay Wason, Tim Callahan, Charlotte Ruth Levy, and Matt Glaub helped with field work, Mariano Arias helped with data entry, and Deian Moore assisted with map making. We thank the Dovciak plant ecology lab members for useful and critical feedback. We thank Gregory McGee for his helpful review of the manuscript. Any use of trade, firm, or product names is for descriptive purposes only and does not imply endorsement by the U.S. Government.

Open Access This article is distributed under the terms of the Creative Commons Attribution 4.0 International License (http:// creativecommons.org/licenses/by/4.0/), which permits unrestricted use, distribution, and reproduction in any medium, provided you give appropriate credit to the original author(s) and the source, provide a link to the Creative Commons license, and indicate if changes were made.

\section{References}

Baker JP, Gherini SA, Christiansen SW, et al (1990) Adirondack Lakes survey: an interpretive analysis of fish communities and water chemistry, 1984-1987. Adirondack Lakes Survey Corporation, Ray Brook. https://doi.org/10.2172/6173689

Bartels SF, Chen HYH (2010) Is understory plant species diversity driven by resource quantity or resource heterogeneity? Ecology 91:1931-1938. https://doi.org/10.1890/09-1376.1

Bedison J, Johnson A (2010) Seventy-four years of calcium loss from forest soils of the Adirondack Mountains, New York. Soil Sci Soc Am J 74:2187-2195. https://doi.org/10.2136 /sssaj2009.0367

Beier CM, Woods AM, Hotopp KP et al (2012) Changes in faunal and vegetation communities along a soil calcium gradient in northern hardwood forests. Can J For Res 42:1141-1152. https://oi.org/10.1139/x2012-071
Bishop DA, Beier CM, Pederdon N et al (2015) Regional growth decline of sugar maple (Acer saccharum) and its potential causes. Ecosphere 6. https://doi.org/10.1890/ES15-00260.1

Blois J, Williams J, Fitzpatrick M et al (2013) Space can substitute for time in predicting climate-change effects on biodiversity. Proc Natl Acad Sci 110:9374-9379. https://doi.org/10.1073 /pnas. 1220228110

Bobbink R, Hicks K, Galloway J et al (2010) Global assessment of nitrogen deposition effects on terrestrial plant diversity: a synthesis. Ecol Appl 20:30-59. https://doi.org/10.1890/081140.1

Cardinale BJ, Duffy JE, Gonzalez A et al (2012) Biodiversity loss and its impact on humanity. Nature 486:59-67. https://doi. org/10.1038/nature11148

Chen ZC, Ma JF (2013) Magnesium transporters and their role in Al tolerance in plants. Plant Soil 368:51-56. https://doi. org/10.1007/s11104-012-1433-y

Church MR (1997) Hydrochemistry of forested catchments. Annu Rev Earth Planet Sci 25:23-59. https://doi.org/10.1146 /annurev.earth.25.1.23

Daubenmire RF (1959) A canopy-coverage method of vegetational analysis. Northwest Sci 33:43-64

DeHayes DH, Schaberg PG, Hawley GJ, Strimbeck GR (1999) Acid rain impacts on calcium nutrition and forest health: alteration of membrane-associated calcium leads to membrane destabilization and foliar injury in red spruce. Bioscience 49:789-800. https://doi.org/10.2307/1313570

Dovciak M, Halpern CB (2010) Positive diversity-stability relationships in forest herb populations during four decades of community assembly. Ecol Lett 13:1300-1309. https://doi. org/10.1111/j.1461-0248.2010.01524.x

Driscoll CT, Lawrence GB, Bulger AJ et al (2001) Acidic deposition in the northeastern United States: sources and inputs, ecosystem effects, and management strategies. Bioscience 51:180-198. https://doi.org/10.1641/00063568(2001)051[0180:ADITNU]2.0.CO;2

ESRI (2018) ArcGIS Desktop. 10.6.1

Fox J, Weisberg S (2011) An $\{R\}$ companion to applied regression, 2nd edn. Sage Publications, Thousand Oaks

Frelich LE, Machado J, Reich PB (2003) Fine-scale environmental variation and structure of understorey plant communities in two old-growth pine forests. J Ecol 91:283-293. https://doi. org/10.1046/j.1365-2745.2003.00765.x

Gessler PE, Moore ID, McKenzie NJ, Ryan PJ (1995) Soillandscape modelling and spatial prediction of soil attributes. Int J Geogr Inf Syst 9:421-432. https://doi.org/10.1080 /02693799508902047

Gilliam FS (2006) Response of the herbaceous layer of forest ecosystems to excess nitrogen deposition. J Ecol 94:11761191. https://doi.org/10.1111/j.1365-2745.2006.01155.x

Gilliam FS (2007) The ecological significance of the herbaceous layer in temperate forest ecosystems. Bioscience 57:845858. https://doi.org/10.1641/B571007

Gilliam FS (ed) (2014) The herbaceous layer in forests of eastern North America, 2nd edn. Oxford University Press, New York

Gilliam FS, Hockenberry AW, Adams MB (2006) Effects of atmospheric nitrogen deposition on the herbaceous layer of a central Appalachian hardwood forest. J Torrey Bot Soc 133: 240-254. https://doi.org/10.3159/1095-5674(2006)133[240: EOANDO]2.0.CO;2 
Gilliam FS, Welch NT, Phillips AH et al (2016) Twenty-five-year response of the herbaceous layer of a temperate hardwood forest to elevated nitrogen deposition. Ecosphere 7. https://doi.org/10.1002/ecs2.1250

Gleason HA, Cronquist A (1991) Manual of vascular plants of northeastern United States and adjacent Canada, 2nd edn. New York Botanical Garden, New York

Greaver TL, Sullivan TJ, Herrick JD et al (2012) Ecological effects of nitrogen and sulfur air pollution in the US: what do we know? Front Ecol Environ 10:365-372. https://doi. org/10.1890/110049

Hardtle W, von Oheimb G, Westphal C (2003) The effects of light and soil conditions on the species richness of the ground vegetation of deciduous forests in northern Germany (Schleswig-Holstein). For Ecol Manag 182:327-338. https://doi.org/10.1016/S0378-1127(03)00091-4

Harrell FEJ (2015) Regression modeling strategies: with applications to linear models, logistic and ordinal regression, and survival analysis, 2 nd edn. Springer, Cham

Hill JD, Silander JA (2001) Distribution and dynamics of two ferns: Dennstaedtia punctilobula (Dennstaedtiaceae) and Thelypteris noveboracensis (Thelypteridaceae) in a northeast mixed hardwoods-hemlock forest. Am J Bot 88:894-902. https://doi.org/10.2307/2657041

Holmgren NH (1998) Illustrated companion to Gleason and Cronquist's manual. Illustrations of the vascular plants of Northeastern United States and adjacent Canada. The New York Botanical Garden, Bronx

Horrigue W, Dequiedt S, Chemidlin Prévost-Bouré N et al (2016) Predictive model of soil molecular microbial biomass. Ecol Indic 64:203-211. https://doi.org/10.1016/j. ecolind.2015.12.004

Horsley SB, Long RP, Bailey SW et al (2000) Factors associated with the decline disease of sugar maple on the Allegheny plateau. Can J For Res 30:1365-1378. https://doi. org/10.1139/x00-057

Horsley SB, Bailey SW, Ristau TE et al (2008) Linking environmental gradients, species composition, and vegetation indicators of sugar maple health in the northeastern United States. Can J For Res 38:1761-1774. https://doi.org/10.1139/x08907

Huebner CD, Steinman J, Hutchinson TF et al (2014) The distribution of a non-native (Rosa multiflora) and native (Kalmia latifolia) shrub in mature closed-canopy forests across soil fertility gradients. Plant Soil 377:259-276. https://doi. org/10.1007/s11104-013-2000-x

Hurd TM, Brach AR, Raynal DJ (1998) Response of understory vegetation of Adirondack forests to nitrogen additions. Can J For Res 28:799-807. https://doi.org/10.1139/x98-045

Ito M, Mitchell MJ, Driscoll CT (2002) Spatial patterns of precipitation quantity and chemistry and air temperature in the Adirondack region of New York. Atmos Environ 36:10511062. https://doi.org/10.1016/S1352-2310(01)00484-8

Iverson LR, Dale ME, Scott CT, Prasad A (1997) A GIS-derived integrated moisture index to predict forest composition and productivity of Ohio forests (U.S.A.). Landsc Ecol 12:331348. https://doi.org/10.1023/a:1007989813501

Janssen BH (1996) Nitrogen mineralization in relation to C:N ratio and decomposability of organic materials. Plant Soil 181:3945. https://doi.org/10.1007/BF00011290
Johnson AH, Moyer A, Bedison JE et al (2008) Seven decades of calcium depletion in organic horizons of Adirondack forest soils. Soil Sci Soc Am J 72:1824-1830. https://doi. org/10.2136/sssaj2006.0407

Lawrence G, David M, Shortle W (1995) A new mechanism for calcium loss in forest-floor soils. Nature 378:162-165. https://doi.org/10.1038/378162a0

Lawrence GB, Baldigo BP, Roy KM, et al (2008) Results from the 2003-2005 Western Adirondack Stream Survey. NYSERDA Report 08-22. New York State Energy Research and Development Authority, Albany

Lawrence GB, Hazlett PW, Fernandez IJ et al (2015a) Declining acidic deposition begins reversal of forest-soil acidification in the northeastern U.S. and eastern Canada. Environ Sci Technol 49:13103-13111. https://doi.org/10.1021/acs.est.5 b02904

Lawrence GB, Sullivan TJ, Burns DA, et al (2015b) Acidic deposition along the Appalachian Trail corridor and its effects on acid-sensitive terrestrial and aquatic resources: Results of the Appalachian Trail MEGA-Transect Atmospheric Deposition Study. Natural resource report NPS/NRSS/ARD/NRR - 2015/996. USDI, National Park Service, Fort Collins

Lawrence GB, McDonnell TC, Sullivan TJ et al (2017a) Soil base saturation combines with beech bark disease to influence composition and structure of sugar maple-beech forests in an acid rain-impacted region. Ecosystems 21:795-810. https://doi.org/10.1007/s10021-017-0186-0

Lawrence GB, Sullivan TJ, Bailey SW, et al (2017b) Adirondack New York soil chemistry data, 1997-2014: U.S. Geological Survey data release. https://doi.org/10.5066/F78050TR

Lemmon PE (1956) A spherical densiometer for estimating forest overstory density. For Sci 2:314-320

Lovett GM, Mitchell MJ (2004) Sugar maple and nitrogen cycling in the forests of eastern North America. Front Ecol Environ 2: 81-88. https://doi.org/10.2307/3868214

Lovett GM, Weathers KC, Arthur MA, Schultz JC (2004) Nitrogen cycling in a northern hardwood forest: do species matter? Biogeochemistry 67:289-308. https://doi. org/10.1023/B:BIOG.0000015786.65466.f5

Lumley T (2009) Leaps: Regression subset selection 2.9

Mazerolle MJ (2016) AICcmodavg: Model selection and multimodel inference based on (Q)AIC(c). 2.0-4

McCune B, Mefford MJ (2011) PC-ORD. Multivariate analysis of ecological data 7

McDonough AM, Watmough SA (2015) Impacts of nitrogen deposition on herbaceous ground flora and epiphytic foliose lichen species in southern Ontario hardwood forests. Environ Pollut 196:78-88. https://doi.org/10.1016/j. envpol.2014.09.013

McLaughlin SB, Wimmer R (1999) Tansley review no. 104. Calcium physiology and terrestrial ecosystem processes. New Phytol 142:373-417. https://doi.org/10.1046/j.14698137.1999.00420.x

McNab WH, Cleland DT, Freeouf JA, et al (2007) Description of "ecological subregions: sections of the conterminous United States." Gen. Tech. Report WO-76B. USDA Forest Service, Washington

Ollinger SV, Aber JD, Lovett GM et al (1993) A spatial model of atmospheric deposition for the northeastern U.S. Ecol Appl 3:459-472. https://doi.org/10.2307/1941915 
Parmesan C (2006) Ecological and evolutionary responses to recent climate change. Annu Rev Ecol Evol Syst 37:637669 . https://doi.org/10.1146/annurev. ecolsys.37.091305.110100

Pausas JG, Austin MP (2001) Patterns of plant species richness in relation to different environments: an appraisal. J Veg Sci 12: 153-166. https://doi.org/10.2307/3236601

Peck JE (2010) Multivariate analysis for community ecologists: Step-by-Step using PC-ORD. MjM Software Design, Gleneden Beach

Purse BV, Falconer D, Sullivan MJ et al (2012) Impacts of climate, host and landscape factors on Culicoides species in Scotland. Med Vet Entomol 26:168-177. https://doi.org/10.1111 j.1365-2915.2011.00991.x

R Development Core Team (2016) R: A language and environment for statistical computing. 1.0.136

Rainey SM, Nadelhoffer KJ, Silver WL, Downs MR (1999) Effects of chronic nitrogen additions on understory species in a red pine plantation. Ecol Appl 9:949-957. https:// doi.org/10.1890/1051-0761 (1999)009[0949: EOCNAO]2.0.CO;2

Romero-Lankao P, Smith J, Davidson D, et al (2014) Climate change 2014: Impacts, adaptation, and vulnerability. Part B: Regional aspects. Contribution of Working Group II to the Fifth Assessment Report of the Intergovernmental Panel on Climate Change. IPCC, Geneva

SAS Institute Inc. (2015) SAS University Edition

Schlesinger W (1997) Biogeochemistry: an analysis of global change, 2nd edn. Academic Press, San Diego

Schuster B, Diekmann M (2003) Changes in species density along the soil $\mathrm{pH}$ gradient - evidence from German plant communities. Folia Geobot 38:367-379. https://doi.org/10.1007 /BF02803245

Schwarz G (1978) Estimating the dimension of a model. Ann Stat 6:461-464. https://doi.org/10.1214/aos/1176344136

Schwede DB, Lear GG (2014) A novel hybrid approach for estimating total deposition in the United States. Atmos Environ 92:207-220. https://doi.org/10.1016/j. atmosenv.2014.04.008

Shaul O (2002) Magnesium transport and function in plants: the tip of the iceberg. BioMetals 15:309-323. https://doi. org/10.1023/a:1016091118585

Shortle WC, Smith KT (1988) Aluminum-induced calcium deficiency syndrome in declining red spruce. Science 240:10171018. https://doi.org/10.1126/science.240.4855.1017

Shurin JB, Winder M, Adrian R et al (2010) Environmental stability and lake zooplankton diversity - contrasting effects of chemical and thermal variability. Ecol Lett 13:453-463. https://doi.org/10.1111/j.1461-0248.2009.01438.x
Simkin SM, Allen EB, Bowman WD et al (2016) Conditional vulnerability of plant diversity to atmospheric nitrogen deposition across the United States. Proc Natl Acad Sci 113:40864091. https://doi.org/10.1073/pnas.1515241113

Sullivan TJ, Cosby BJ, Driscoll CT et al (2011) Target loads of atmospheric sulfur deposition to protect terrestrial resources in the Adirondack Mountains, New York against biological impacts caused by soil acidification. J Environ Stud Sci 1: 301-314. https://doi.org/10.1007/s13412-011-0062-8

Sullivan TJ, Lawrence G, Bailey S, et al (2013a) Effects of acidic deposition and soil acidification on sugar maple trees in the Adirondack Mountains, New York. NYSERDA Report 1304. New York State Energy Research and Development Authority, Albany

Sullivan TJ, Lawrence GB, Bailey SW et al (2013b) Effects of acidic deposition and soil acidification on sugar maple trees in the Adirondack Mountains, New York. Environ Sci Technol 47:12687-12694. https://doi.org/10.1021/es401864 $\mathrm{w}$

USDA NCRS (2016) The PLANTS Database (http://plants.usda. gov/java/)

USGS (1999) 30 Meter resolution, one-sixtieth degree national elevation dataset for CONUS, Alaska, Hawaii, Puerto Rico, and the U. S. Virgin Islands. Edition 1 (https://www.epa. gov/exposure-assessment-models/metadata-nationalelevation-dataset-ned)

USGS and NYS DEC (2015) NYS elevation data (http://gis.ny. gov/elevation/)

van Dobben H, de Vries W (2010) Relation between forest vegetation, atmospheric deposition and site conditions at regional and European scales. Environ Pollut 158:921-933. https://doi.org/10.1016/j.envpol.2009.09.015

Vitousek PM, Mooney HA, Lubchenco J, Melillo JM (1997) Human domination of Earth's ecosystems. Science 277: 494-499. https://doi.org/10.1007/978-0-387-73412-5_1

Warby RAF, Johnson CE, Driscoll CT (2009) Continuing acidification of organic soils across the northeastern USA: 1984 2001. Soil Sci Soc Am J 73:274-284. https://doi.org/10.2136 /sssaj2007.0016

Wason JW, Dovciak M, Beier CM, Battles JJ (2017) Tree growth is more sensitive than species distributions to recent changes in climate and acidic deposition in the northeastern United States. J Appl Ecol 54:1648-1657. https://doi.org/10.1111 /1365-2664.12899

Publisher's note Springer Nature remains neutral with regard to jurisdictional claims in published maps and institutional affiliations. 